\title{
Aging Is Associated with Increased Human T Cell CC Chemokine Receptor Gene Expression
}

\author{
RAYMOND L. YUNG and RURAN MO
}

\begin{abstract}
Leukocyte chemokine receptors (CR) are central to the pathogenesis of many human diseases, including human immunodeficiency virus-1 (HIV-1) infection. Elderly individuals infected with the HIV-1 virus have a shorter disease-free interval and worse clinic outcome. However, the reasons for this are unclear. We recently reported increased $\mathrm{CC}$ chemokine receptor $(\mathrm{CCR})$ expression in $\mathrm{CD4}^{+} \mathrm{T}$ cells in aged mice, but it is not known if similar changes occur in humans. In addition, it is unclear if the observed differences are related to agedrelated expansion in the memory $T$ cell compartment. In this report, we examined the effects of aging on CCR gene expression in human peripheral blood mononuclear cells (PBMCs), $\mathrm{CD}^{+} \mathrm{T}$ cells, and naive/memory $\mathrm{T}$ cells. Aging is found to be associated with increased CCR1-5 expression in PBMCs and $\mathrm{CD4}^{+} \mathrm{T}$ cells. In addition, although the age-related increases in CCR expression occurred in both naive and memory $T$ cells, the greatest changes were seen in the memory $T$ cell subset. We propose that the observed aging-associated increase in $T$ cell chemokine receptor expression may contribute to the worse clinical outcome of $T$ cell chemokine receptor-dependent disease, such as HIV-1 infection, in the elderly.
\end{abstract}

\section{INTRODUCTION}

$\mathbf{H}$ UMAN Aging Is ASSOCIATED With THE DECLINE in the ability to defend against a multitude of infections, including the human immunodeficiencytype 1 (HIV-1) virus. People $\geq 50$ years constitute at least $10 \%$ of new acquired immunodeficiency syndrome (AIDS) cases, representing the fastest growing HIV1 -infected group. ${ }^{(1)}$ Studies have shown that older patients have a shorter observed AIDS-free interval and shorter survival, along with more HIV and non-HIV-related comorbidity. ${ }^{(2-5)}$ Although the underlying cause for the discrepancy is unclear, the increase in disease susceptibility and worse clinical outcome in HIV-1 infection in the elderly are often attributed to poor immunity in old age.

Chemokines, or chemotactic cytokines, and their counterreceptors are increasingly recognized as critical components of many normal and pathologic processes. ${ }^{(6,7)}$ Depending on the arrangement of the amino-terminal cysteine residues, these 7-11-kDa proteins are classified into four subfamilies: CC, CXC, $\mathrm{C}$, and CX3C. Bone marrow-derived cells are the main targets of chemokines. Expression of the chemokine receptors on leukocytes and the abundance of chemokines in the local environment play critical roles in the guided migration of leukocytes to areas of inflammation and immune response. The leukocyte chemokine system received exponential attention when it was discovered that specific chemokine receptors are the required coreceptors for the productive entry of HIV-1 and HIV-2 isolates into $\mathrm{T}$ cells and monocytes. ${ }^{\left({ }^{(8)}\right)}$ The level of $\mathrm{CD}^{+}{ }^{+} \mathrm{T}$ cell chemokine receptor expression correlates closely to HIV viral load ${ }^{(10)}$ and disease progression. ${ }^{(1)}$ However, despite the established importance of the chemokine system in normal and pathologic immune responses, very little is known about this aspect of immunobiology in aging.

We recently examined the effect of aging on the expression and function of murine $\mathrm{CD} 4^{+} \mathrm{T}$ cell chemokine receptors. ${ }^{(12)}$ $\mathrm{CD}^{+}{ }^{+} \mathrm{T}$ cells from aged C57BL/6 and DBA/2 mice were shown to overexpress the CC chemokine receptors CCR1, 2, 4, 5, 6, and 8 and have lower expression of CCR7 and 9. The increased chemokine receptor gene expression correlates with increased protein expression and has important function consequences. The difference in $\mathrm{T}$ cell chemokine receptor expression is regulated at the transcriptionalor pretranscriptionallevel, as RNA degradation studies showed equal or faster rate of chemokine receptor RNA degradation in old vs. young T cells. Furthermore, caloric restriction partially or completely restored the aging changes. Expansion of the T memory cell compartment occurs in both human and murine aging. ${ }^{(13)}$ It is, therefore, possible that the observed chemokine receptor changes in $\mathrm{T}$ cells reflect the aging-associatedshift in favor of memory CD4 ${ }^{+}$ $\mathrm{T}$ cells. In this report, we asked if $\mathrm{T}$ cell $\mathrm{CC}$ chemokine re- 
ceptor changes also occur in human aging and if these changes occur in both the naive and memory CD $4^{+} \mathrm{T}$ cell subsets. This is an important question, as there are species-specific differences in chemokine receptor function. An important example is that unlike their human counterparts, unmanipulated murine $\mathrm{T}$ cells are resistant to HIV-1 infection.

\section{MATERIALS AND METHODS}

\section{Human subjects}

Community-dwelling adults aged $\geq 60$ years were recruited from the Human Subject Core of the Institution of Gerontology and the outpatient geriatrics clinic at the University of Michigan. All participants gave informed consent, and the protocol was approved by the institutional review board of the University of Michigan. Young adults between the ages of 18 and 40 years were recruited by local advertising. Subjects $<18$ years were excluded from the study to avoid detecting developmental rather than aging-related changes. Exclusion criteria for both young and old subjects included any history of recent $(<2$ weeks) or chronic infection, cancer, immune/autoimmune, or any inflammatory condition requiring therapy with corticosteroids or immunomodulating agents, or significant anemia (hematocrit $<38 \%$ ).

\section{$T$ cell isolation}

Peripheral blood mononuclear cells (PBMC) were isolated from venous blood by density gradient centrifugation using Ficoll-Plaque $^{\circledR}$ Plus (Amersham Pharmacia Biotec, Piscataway $\mathrm{NJ}$ ). $\mathrm{CD}^{+}{ }^{+}, \mathrm{CD} 4{ }^{+} \mathrm{CD} 45 \mathrm{RA}$ (naive), and $\mathrm{CD} 4{ }^{+} \mathrm{CD} 45 \mathrm{RO}$ (memory) cells were isolated using magnetic cell separation (MACS) MicroBeads technology (Miltenyi Biotec GmbH, Bergisch Gladbach, Germany) as before ${ }^{(12)} \mathrm{CD} 4^{+}$cells were negatively selected using the human CD4 MultiSort Kit (Miltenyi Biotec). For isolation of naive and memory cells, the isolated $\mathrm{CD}^{+}{ }^{+}$cells were labeled with anti-CD45RA and anti-CD45RO Microbeads, respectively. Purity of the subpopulations was checked by staining with the appropriate cell surface markers and was consistently between $96 \%$ and $99 \%$. RNAs were isolated by TRIzol LS reagent (Life Technologies, Grand Island, NY), and a second cleanup step was performed using the Qiagen RAeasy total RNA isolation kit (Qiagen, Valencia, CA).

\section{Ribonuclease protection assays (RPA)}

Age-related changes in T cell chemokine receptor gene expression were examined by RPAs. The probes were synthesized by modification of the manufacturer's protocol. Briefly, GACU nucleotide pool and $\alpha^{32} \mathrm{P}-\mathrm{UTP}, \mathrm{RNasin}, \mathrm{T} 7 \mathrm{RNA}$ polymerase were added to the multiprobe template set hCR-5 (CCR-1, -3, $-4,-5,-8,-2 \mathrm{a} / \mathrm{b},-2 \mathrm{a},-2 \mathrm{~b})$ (BD PharMingen, San Diego, CA) and placed on a heat block at $37^{\circ} \mathrm{C}$ for $1 \mathrm{~h}$. The reaction was terminated by adding DNAse and incubated at $37^{\circ} \mathrm{C}$ on a heat block for $30 \mathrm{~min}$. Appropriate volumes of EDTA, Tris-saturated phenol, chloroform/isoamyl alcohol (CIAA, 50:1), and yeast tRNA were then added to the mixture, as suggested by the manufacturer. The aqueous layer was extracted by CIAA, then pelleted by adding a 1:5, $4 \mathrm{M}$ ammonium acetate and ice- cold $100 \%$ ethanol mixture. Total RNA $(5 \mu \mathrm{g})$ from each T cell sample was used for hybridization. The protected probes were allowed to be resolved by electrophoresis using a 5\% acrylamide gel, exposed to a phosphor screen, and quantified by a PhosphorImager using Image Quant software (Molecular Dynamics, Sunnyvale, CA).

\section{Western blots}

To determine if changes in chemokine receptor expression caused similar changes in protein expression, Western blot analyses were performed as before. ${ }^{(12)}$ Briefly, proteins were isolated from $\mathrm{CD}^{+}{ }^{+} \mathrm{T}$ cells from 14 young and 14 old subjects and resolved on $10 \%$ SDS-PAGE, then transferred to nitrocellulose-1 membranes (Life Technologies, Gaithersburg, MD). The membranes were allowed to react with antihuman CCR4 and CCR5 antibodies (Research Diagnostics Inc., Flanders, NJ). Detection was performed using the ECL system (Amersham Life Science). The membranes were stripped and reprobed with anti- $\beta$-actin antibodies (Sigma-Aldrich, St. Louis, MO) to confirm equal protein loading.

\section{Statistical analysis}

Data analysis was performed with Stata 7.0 (Stata Corporation, College Station, TX). The results are expressed as the mean \pm standard error. Where indicated, comparisons between young and old $\mathrm{T}$ cells were carried out using the nonparametric Mann-Whitney U-test, as chemokine receptor levels may not be normally distributed in either age group. A $p$ value $\leq 0.05$ is considered significant.

\section{RESULTS}

\section{Effect of aging on PBMC CC chemokine receptor expression}

To determine if the observed aging-associated increased CC chemokine receptor expression in murine $\mathrm{T}$ cells also occurs in humans, CC chemokine receptor expression of PBMCs from young $(n=15$; mean age 25 years, range $20-32)$ and old $(n=$ 14; mean age 73 years, range 60-80) subjects was examined by RPAs. The results showed that aging is associated with significant increased gene expression of CCR1-5 (Fig. 1).

\section{Effect of aging on $\mathrm{CD}^{+} \mathrm{T}$ cell CC chemokine receptor expression}

We then determined if the age-related changes occurred in specific $\mathrm{T}$ cell compartments in humans. CC chemokine receptor expression of $\mathrm{CD}^{+}{ }^{+}$from young $(n=16$; mean age 27 years, range 20-39) and old ( $n=14$; mean age 78 years, range 66-95) subjects was examined by RPA. The results were similar to those for total PBMCs, with increased CCR1-5 in CD4 ${ }^{+}$ $\mathrm{T}$ cells in human aging (Fig. 2).

\section{Effect of aging on naive and memory $C D 4^{+} T$ cell $C C$ chemokine receptor expression}

Aging is associated with the expansion of the T memory cell compartment. Selective CC chemokine receptors are also pref- 


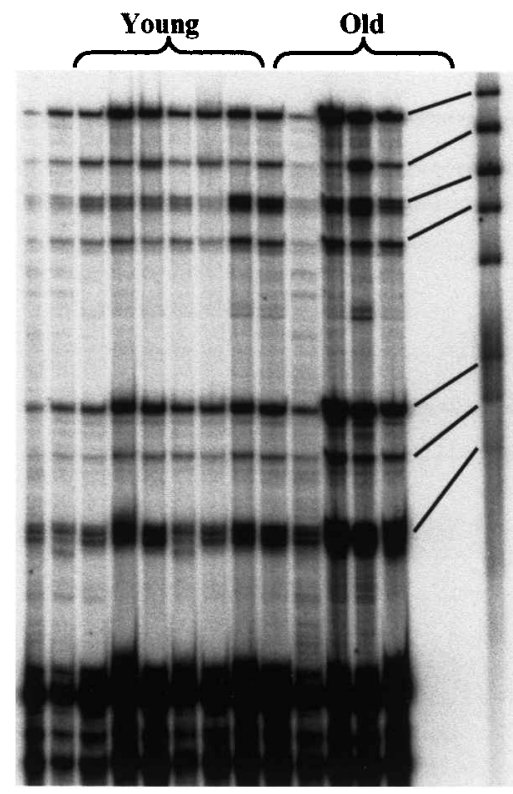

CCR I

$\mathrm{CCR} 3$

CCR4

CCR5

CCR8

\section{CCR1}

CCR2a/b

CCR2a

CCR2b

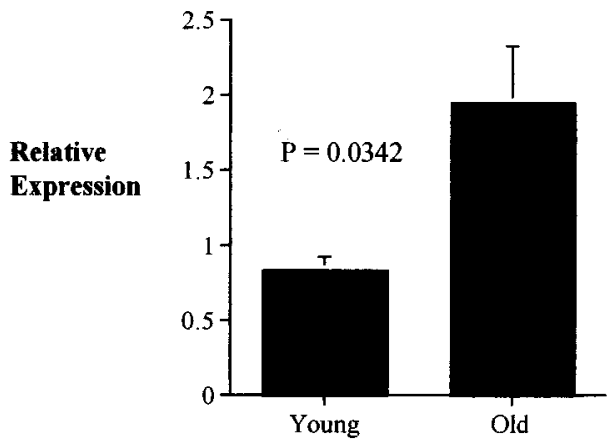

GAPDH
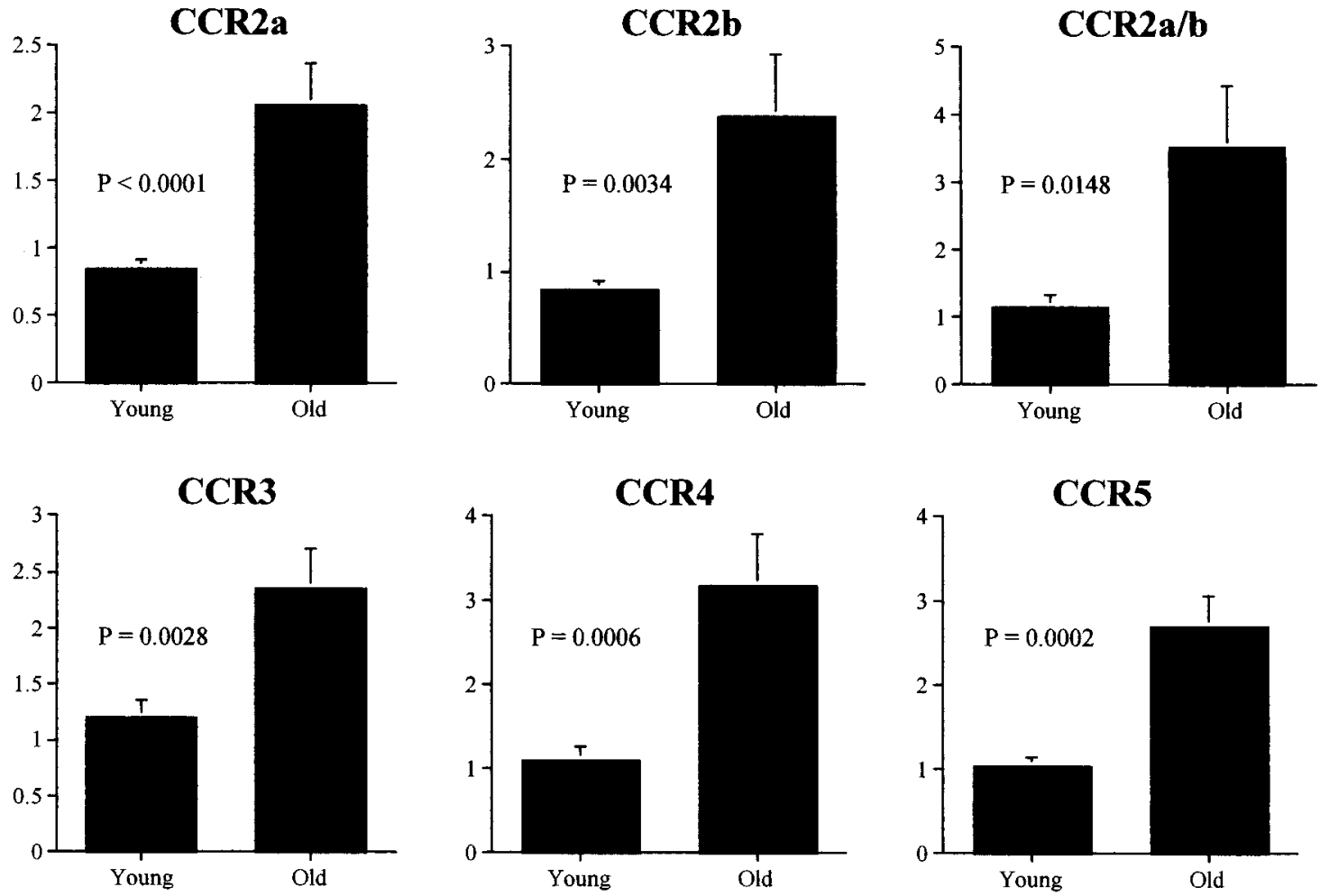

FIG. 1. CCR1-5 gene expression in PBMCs in aging as measured by RPA. CCR1-5 gene expression in PBMCs from 15 young and 14 old subjects was measured. An autoradiograph of representative RPA showing CR gene expression of 7 young and 6 old subjects is shown. The bar graphs represent the $p$ value and mean \pm SEM of each of the CR measured. Gel loading is corrected with L32 expression. $p$ values comparing young and old are shown. The level of CCR8 gene expression is considered too low to be reliable.

erentially expressed in memory vs. naive T cells. To exclude the possibility that the observed aging-associated increase in $\mathrm{CC}$ chemokine receptor represents changes in $\mathrm{CD} 4^{+} \mathrm{T}$ cell subsets, we determined the CCR $1-5$ expression in naive and mem- ory $\mathrm{CD}^{+}$T cells in young $(n=8$; mean age $27.9 \pm 6.0$ years, range $20-38)$ and old $(n=8$; mean age $77.6 \pm 8.8$ years, range $67-95)$ subjects. The results show that the aging effects were present in both the naive and memory subsets. However, the 

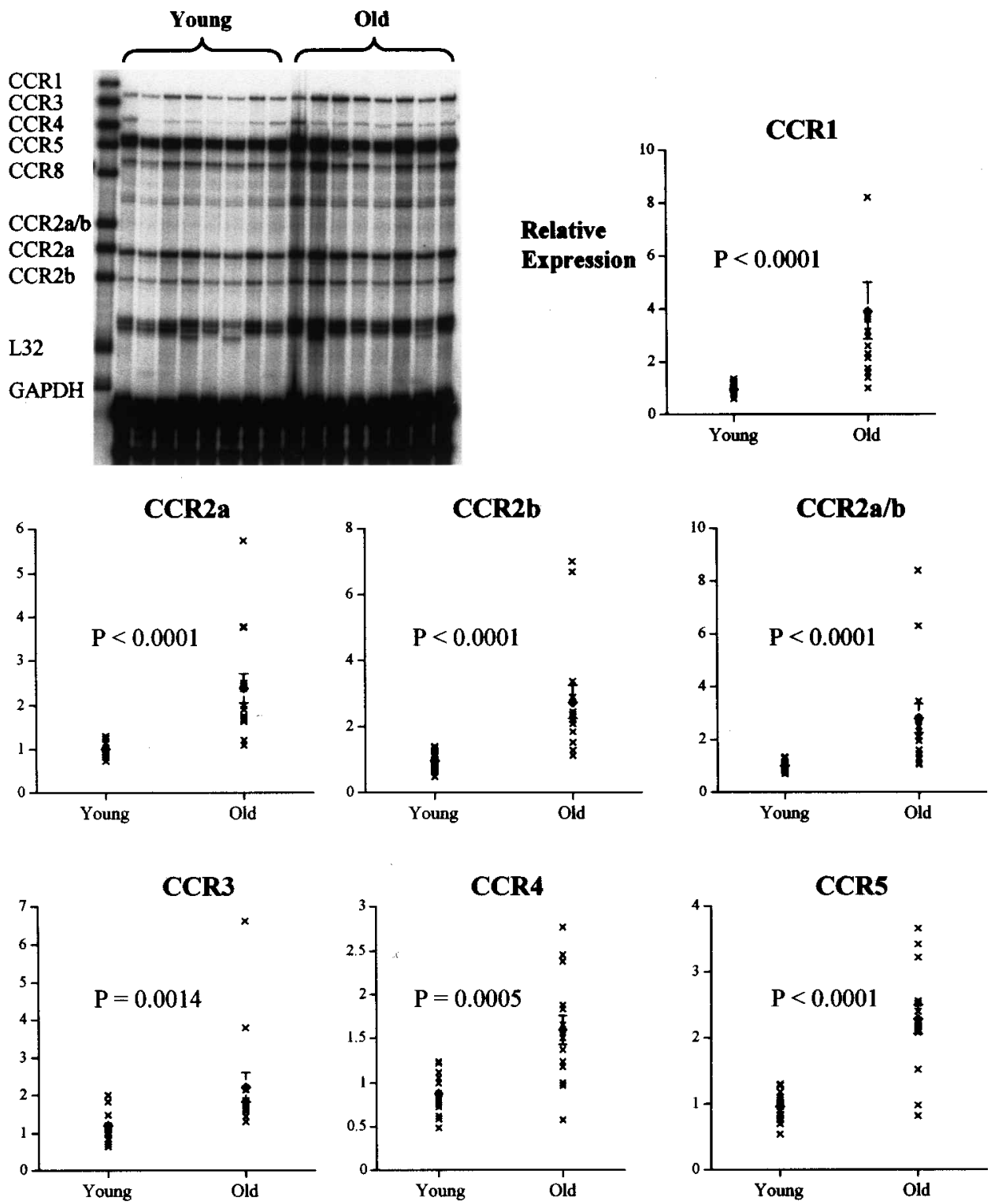

FIG. 2. The effects of aging on $\mathrm{CD} 4^{+} \mathrm{T}$ cell CCR $1-5$ gene expression as measured by RPA. CD $4^{+}$T cells were isolated from 16 young and 14 old subjects by magnetic beads. RNAs from the freshly isolated cells were subjected to RPA. The intensity of the bands was quantified using a PhosphorImager. A representative autoradiograph is shown. Gel loading is corrected with L32 expression. The results represent the $p$ values and the mean \pm SEM and are similar to the results obtained with the PBMCs.

biggest increase in CCR expression occurred in the memory $\mathrm{CD}^{+}$cell compartment (Fig. 3), suggesting that the primary defects reside in the memory $\mathrm{T}$ cell subset.

\section{Effects of aging on $\mathrm{CD}^{+} \mathrm{T}$ cell CC chemokine receptor protein expression}

In general, the chemokine receptor protein levels are quite low in unstimulated T cells. However, consistent with the RPA data, the Western blot results showed increased CCR4 and CCR5 protein levels in CD4 ${ }^{+} \mathrm{T}$ cells from old $(n=14$; mean age $77.5 \pm 10.3$ years, range 60-95) compared with 14 young $(n=14$, mean age $25.4 \pm 5.8$ years, range 20-39) subjects (Fig. 4).

\section{DISCUSSION}

HIV-1 infection in the elderly is the fastest growing segment of the AIDS epidemic in this country. Because of the graying of America, coupled with the lack of awareness/misconception of many healthcare professionals, older adults with HIV-1 infection have been called the "overlooked epidemic" and the "forgotten population."(14) In addition to having a shorter observed AIDS-free interval, older adults infected with the HIV virus have more severe disease and shorter survival. ${ }^{(1-5)}$ However, the reasons behind these observations are unclear. Postulated mechanisms include cofactors, such as poor nutrition, coexisting infections, and other aging-related comorbidities. It also has been suggested that higher levels of $\mathrm{P}$-glycoprotein $(\mathrm{P}-$ 

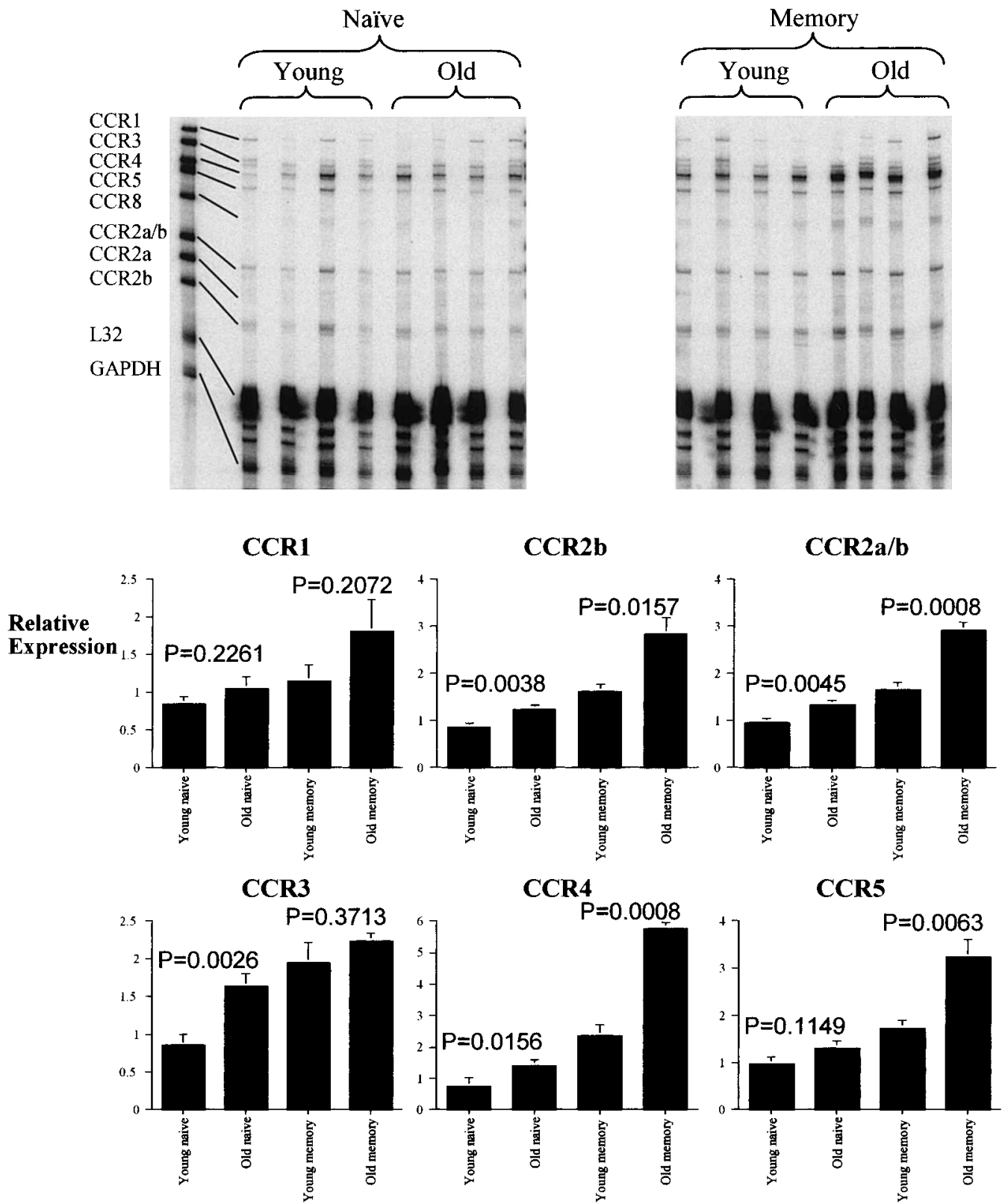

CCR5

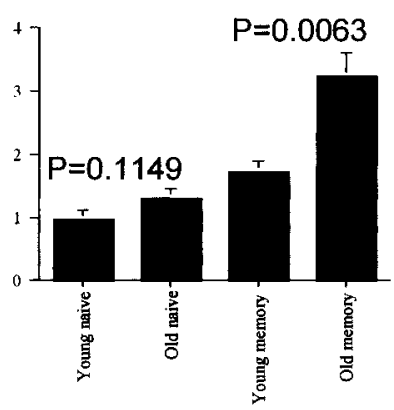

FIG. 3. RPAs showing the effects of aging on CCR $1-5$ gene expression of naive and memory CD $4^{+} \mathrm{T}$ cells. Naive and memory cells were isolated from 8 young (mean age 28 years) and 8 old (mean age 78 years) subjects. The results represent the mean \pm SD of the 8 subjects in each of the four groups. The $p$ values are also shown.

gp), the ATP-dependent plasma membrane pump that mediates multiple drug resistance, in aged $\mathrm{T}$ cells lead to resistance to antiviral medications. ${ }^{(15)}$ Poor antibody response and poor performance by $\mathrm{T}$ lymphocytes of older adults ${ }^{(16)}$ also have been proposed as possible factors causing the worse HIV clinical outcome in the elderly. However, although increased T cell P-gp activity has been demonstrated convincingly in aging rodents, others have found that the proportion of $\mathrm{P}-\mathrm{gp}^{+} \mathrm{T}$ and $\mathrm{B}$ cells increases in human adulthood but declines after age $60 .^{(17)}$

The HIV RNA plasma level has been shown to be the most important predictor of HIV-1 disease progression and outcome. ${ }^{(18)}$ However, there is wide interpatient variability in vi- ral load among HIV-infected patients, and the host factors responsible for this variability are incompletely understood. Several chemokine receptors (CCR2b, CCR3, CCR5, CXCR4) or orphan, chemokine-like molecules (GPR1, GPR15, V28, APJ) have been shown to be coreceptors for HIV-1 entry and replication, but the initially described CXCR4 and CCR5 molecules remain the principal coreceptors for X4 (T cell-tropic or syncytium inducing) or R5 (macrophage [M]-tropic or nonsyncytium inducing) isolates, respectively. ${ }^{(7-9)}$ CCR5 density on $\mathrm{CD}^{+}{ }^{+} \mathrm{T}$ cells has been shown recently to correlate closely to the level of viral load ${ }^{(10)}$ and disease progression. ${ }^{(1)}$ Thus, patients exhibiting high CCR5 expression have high viral load, 


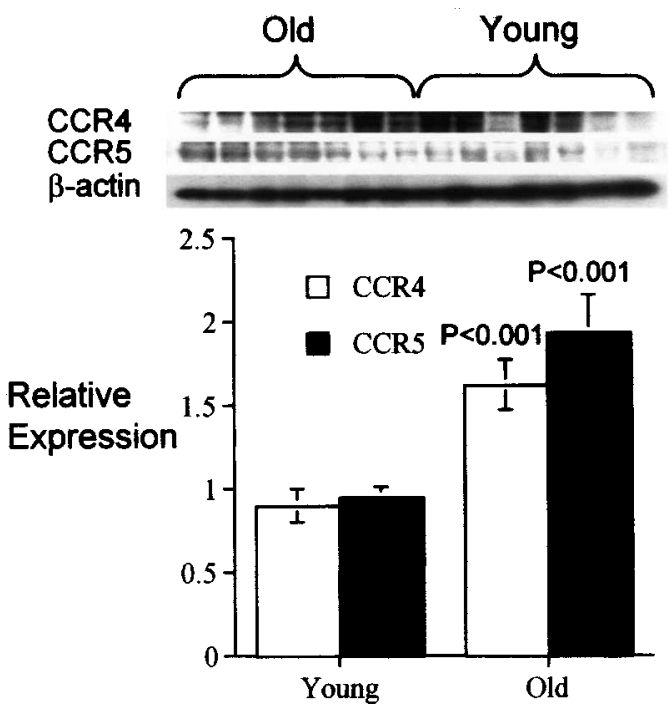

FIG. 4. Western blot analysis of CCR4 and CCR5 protein levels in $\mathrm{CD}^{+}{ }^{+} \mathrm{T}$ cells from 14 young and 14 old subjects. The results are expressed relative to the first young subject (1) and are corrected for protein loading using the $\beta$-actin bands. The results show the mean \pm SEM of $\mathrm{CD}^{+} \mathrm{T}$ cells from young and old subjects. The $p$ values are shown.

and those with low CCR5 expression have low viral load. The importance of CCR5 in HIV-1 is also illustrated by the effect of a 32-bp deletion in the CCR5 gene. Subjects who are homozygous for this $\Delta 32$ deletion have very low levels of CCR5 expression and are resistant to HIV-1 infection. In addition, those with the heterozygous mutation have much slower progression of the disease. ${ }^{(19)}$ Importantly, the correlation between CCR5 expression and viremia is logarithmic. Even a small difference in CCR5 expression causes a marked difference in HIV RNA plasma load.

There is currently very little available information on the effect of aging on $\mathrm{T}$ cell chemokine receptor function. Tarazona et al. ${ }^{(20)}$ showed decreased CCR7 expression on natural killer (NK) cells in elderly individuals and suggested that this is due to the accumulation of memory $\mathrm{T}$ cells. Carramolino et al. ${ }^{(21)}$ recently examined CCR9 expression during development and showed that in mouse thymocytes, CCR9 is expressed at all stages of $\mathrm{T}$ cell maturation, with maximum expression in $\mathrm{CD} 4{ }^{+} \mathrm{CD} 8{ }^{+}$cells. Expression of thymic CCR9 maintains or decreases slightly during the first year of life. The investigators also found that secondary lymphoid organ's CD4 cells lose but CD8 cells maintain CCR9 expression in the neonatal period. The study suggests that age and development affect chemokine receptor expression. However, as the oldest animals examined were only 12 months old, the effect of aging on CCR9 expression is unknown.

We recently examined the effect of aging on murine $\mathrm{T}$ cell chemokine expression by microarray screening and RPA. ${ }^{(12)}$ We showed that $\mathrm{CD} 4^{+} \mathrm{T}$ cells from aged mice had increased CCR1, 2, 4, 5, and 8 and CXCR2-5 and a lower level of CCR7 and 9. CCR3 expression may also be decreased in aging, although the results did not reach statistical significance. In this report, we extended our observations and show for the first time that aging is associated with the increase in human lymphocyte CCR1-5 chemokine receptor expression. Our initial experiments determined CCR1-5 gene expression in unfractionated PBMCs and $\mathrm{CD} 4^{+} \mathrm{T}$ cells from young and old subjects. The results were similar to the murine data and showed increased $\mathrm{T}$ cell CCR1-5 expression in human aging. Both murine and human aging are associated with the accumulation of memory T cells. ${ }^{(13)}$ Naive and memory $\mathrm{T}$ cells also have a different repertoire of chemokine receptors. For example, CCR4, ${ }^{(22)}$ CCR5, and CXCR3 ${ }^{(22,23)}$ expressions are increased in memory $\mathrm{T}$ cells, whereas $\mathrm{CCR} 7^{(24)}$ and $\mathrm{CXCR} 4^{(23)}$ are primarily expressed on naive $\mathrm{T}$ cells. Importantly, naive and memory CD4 ${ }^{+}$ $\mathrm{T}$ cells also differ in their susceptibility to HIV-1 infection, at least in part due to their differential chemokine response to $\mathrm{T}$ cell receptor stimulation. ${ }^{(25,26)}$ Because we did not examine the effect of aging on naive and memory cell chemokine receptor expression in the murine study, it is possible that the observed changes are purely the result of increased memory compartment in aging. In the current study, we isolated naive and memory $\mathrm{CD}^{+}{ }^{+} \mathrm{T}$ cells from the peripheral blood of young and old subjects and showed that the aging-associated increase in CCR occurs in both naive and memory $\mathrm{T}$ cells. This suggests that the observed chemokine receptor changes are not simply the results of bias in favor of T memory subset in the elderly. Furthermore, expression of CCR1, 2, and 3 is not known to be associated with memory $\mathrm{T}$ cells. However, we also found that the most pronounced aging-associated increase in CCR gene expression occurred in the memory CD4 subset. Thus, the expansion of the memory $\mathrm{T}$ cell compartment in aging likely contributes to, but does not fully explain, the observed increased expression of memory CCR markers, including CCR4 and CCR5 in CD4 ${ }^{+}$ T cells.

The mechanisms for the observed increased CCR1-5 expression in aging are unclear. The regulation of gene expression is dependent on the presence of DNA-binding transcription factors and processes determining the ability of transcriptional factors to bind to the target DNA in promoter elements. A number of transcription factors have been shown to be involved in regulating chemokine receptor gene expression. For example, NF- $\kappa$ B consensus binding sequences have been found in the promoter regions of chemokine receptor genes, including CCR5. ${ }^{(27,28)}$ However, others have shown that aging has a tissue-specific effect on transcription factor activity, with a general decline in NF- $\kappa \mathrm{B}$ expression in T cells. ${ }^{(29,30)}$ Furthermore, different $\mathrm{CC}$ chemokine receptor genes are likely regulated by different transcription factors. The decreased transcription factor activity in $\mathrm{T}$ cells in aging is, therefore, not likely to be the mechanism responsible for the observed increased chemokine receptor expression. Interestingly, the human CCR1-3 and 5 are all located on the chromosome locus $3 \mathrm{p} 21.31$, and the CCR4 gene is on $3 \mathrm{p} 24 .^{(7)}$ The close proximity and the concurrent upregulation of these chemokine receptors suggest the possibility that epigenetic mechanisms that affect chromatin structure may be involved in the regulation of chemokine receptor gene expression in aging.

Our current findings may have important implications in our understanding of $\mathrm{T}$ cell chemokine receptor-dependent diseases, including HIV-1 infection, in the elderly. The early stages of HIV-1 infection in vivo are dependent on HIV variants that use CCR5 as the coreceptor for entry into T cells and monocytes. 
The level of T cell CCR5 expression also correlates closely to HIV viral load and disease progression. Importantly, memory $\mathrm{CD}^{+}{ }^{+} \mathrm{T}$ cells are the predominant targets for multiple HIV-1 isolates (both R5 and X4). ${ }^{(31)}$ Thus, our findings that CCR5 overexpression occurs in aging memory $\mathrm{CD}^{+} \mathrm{T}$ cells may provide a mechanism explaining the worse clinical outcome in HIV-1 infection in the elderly.

In summary, we showed that human aging is associated with the increased expression of CCR1-5 in PBMCs and CD4 ${ }^{+} \mathrm{T}$ cells. These changes are not restricted to either memory or naive $\mathrm{T}$ cell subset and are not explained by the expansion of the memory $\mathrm{T}$ cell compartment in aging. The results support the hypothesis that the increased susceptibility and accelerated clinical progression of HIV-1 infection in older adults may be in part due to age-related changes in leukocyte $\mathrm{CC}$ chemokine receptor expression.

\section{ACKNOWLEDGMENTS}

This work was supported by Public Health Service grants 1KO8AR01977-01A1, 1RO1AI42753, and 1RO1HL61577, American Federation for Aging Research Paul Beeson Physician Faculty Scholar Award, and the Geriatrics Research, Education, and Clinical Center of the Ann Arbor Veterans Affair Medical Center

\section{REFERENCES}

1. CENTERS FOR DISEASE CONTROL AND PREVENTION. (1998). AIDS among persons aged greater than or equal to 50 years-United States, 1991-1996. MMWR 47, 21-27.

2. CHIAO, E.Y., RIES, K.M., and SANDE, M.A. (1999). AIDS and the elderly. Clin. Infect. Dis. 28, 740-745.

3. WOOTEN-BIELSKI, K. (1999). HIV and AIDS in older adults. Geriatr. Nurs. 20, 268-272.

4. SZIRONY, T.A. (1999). Infection with HIV in the elderly. J. Gerontol. Nurs. 25, 25-31.

5. SKIEST, D., RUBENSTEIN, E., CARLEY, N., GIORELLA, L., and LYONS, R. (1996). The importance of comorbidity in HIVinfected patients over 55: a retrospective case-control study. Am. J. Med. 101, 605-611.

6. BAGGIOLINI, M. (1998). Chemokines and leukocyte traffic. Nature 392, 565-568.

7. YOSHIE, O., IMAI, T., and NOMIYAMA, H. (2001). Chemokines in immunity. Adv. Immunol. 78, 57-110.

8. BLEUL, C.C., FARZAN, M., CHOE, H., PAROLIN, C., CLARKLEWIS, I., SODROSKI, J., and SPRINGER, T.A. (1996). The lymphocyte chemoattractant SDF-1 is a ligand for LESTR/fusin and blocks HIV-1 entry. Nature 382, 829-833.

9. DORANZ, B.J., RUCKER, J., YI, Y., SMYTH, R.J., SAMSON, M., PEIPER, S.C., PARMENTIER, M., COLLMAN, R.G., and DOMS, R.W. (1996). A dual-tropic primary HIV-1 isolate that uses fusion and the beta-chemokine receptors CKR-5, CKR-3, and CKR-2b as fusion cofactors. Cell 85, 1149-1158.

10. REYNES, J., PORTALES, P., SEGONDY, M., BAILLAT, V., ANDRE, P., REANT, B., AVINENS, O., COUDERC, G., BENKIRANE, M., CLOT, J., ELIAOU, J.F., and COREBEAU, P. (2000). $\mathrm{CD}^{+}{ }^{+} \mathrm{T}$ cell surface CCR5 density as a determining factor of virus load in persons infected with human immunodeficiency virus type 1. J. Infect. Dis. 181, 927-932.

11. REYNES, J., PORTAles, P., SEGONDY, M., BAillat, V.,
ANDRE4, P., AVINENS, O., PICOT, M.C., CLOT, J., and ELIAOU, J.F. (2001). CD4 T cell surface CCR5 density as a host factor in HIV-1 disease progression. AIDS 15, 1627-1634.

12. MO, R., CHEN, J., HAN, Y., BUENO-CANNIZARIES, C., MISEK, D.E., LESCURE, P.A., HANASH, S., and YUNG, R.L. (2003). T cell chemokine receptor expression in aging. J. Immunol. 170, 895-904.

13. YUNG, R.L. (2000). Changes in immune function with age. Rheum. Dis. Clin. North Am. 26, 455-473.

14. WHIPPLE, B., and SCURA, K.W. (1996). The overlooked epidemic: HIV in older adults. Am. J. Nurs. 96, 22-28.

15. GUPTA, S., and GOLLAPUDI, S. (1993). P-glycoprotein (MDR 1 gene product) in cells of the immune system: its possible physiologic role and alteration in aging and human immunodeficiency virus-1 (HIV) infection. J. Clin. Immunol. 13, 289-301.

16. BACHUS, M.A. HIV and the older adult. J. Gerontol. Nurs. 24, 41-46.

17. PILARSKI, L.M., PAINE, D., McELHANCY, J.E., CASS, C.E., and BELCH, A.R. (1995). Multidrug transporter P-glycoprotein 170 as a differentiation antigen on normal human lymphocytes and thymocytes: modulation with differentiation stage and during aging. Am. J. Hematol. 49, 323-325.

18. MELLORS, J.W., RINALDO, C.R., GUPTA, P., WHITE, R.M., TODD, J.A., and KINGSLEY, L.A. (1996). Prognosis in HIV-1 infection predicted by the quantity of virus in plasma. Science $\mathbf{2 7 2}$, $1167-1170$

19. LIU, R., PAXTON, W.A., CHOE, S., CERADINI, D., MARTIN, S.R., HORUK, R., MACDONALD, M.E., STUHLMANN, H., KOUP, R.A., and LANDAU, N.R. (1996). Homozygous defect in HIV-1 coreceptor accounts for resistance of some multiply exposed individuals to HIV-1 infection. Cell 86, 367-377.

20. TARAZONA, R., DElAROSA, O., ALONSO, C., OSTOS, B., ESPEJO, J., PENA, J., and SOLANA, R. (2000). Increased expression of NK cell markers on $\mathrm{T}$ lymphocytes in aging and chronic activation of the immune system reflects the accumulation of effector/senescent T cells. Mech. Ageing Dev. 121, 77-88.

21. CARRAMOLINO, L., ZABALlOS, A., KREMER, L., VILLARES, R., MARTIN, P., ARDAVIN, C., MARTINEZ, A., and MARQUES, C. (2001). Expression of CCR9 beta-chemokine receptor is modulated in thymocyte differentiation and is selectively maintained in $\mathrm{CD} 8^{(+)} \mathrm{T}$ cells from secondary lymphoid organs. Blood 97, 850-857.

22. YAMAMOTO, J., ADACHI, Y., ONOUE, Y., ADACHI, Y.S., OKABE, Y., ITAZAWA, T., TOYODA, M., SEKI, T., MOROHASHI, M., MATSUSHIMA, K., and MIYAWAKI, T. (2000). Differential expression of the chemokine receptors by the Th1- and Th-2 type effector populations within circulating CD $4^{+} \mathrm{T}$ cells. $\mathrm{J}$. Leukocyte Biol. 68, 568-574.

23. SALLUSTO, F., LANZAVECCHIA, A., and MACKAY, C.R. (1998). Chemokines and chemokine receptors in T-cell priming and Th1/Th2-mediated responses. Immunol. Today 19, 568-574.

24. SALLUSTO, F., LENIG, D., FOSTER, R., LIPP, M., and LANZAVECCHIA, A. (1999). Two subsets of memory T lymphocytes with distinct homing potentials and effector functions. Nature $\mathbf{4 0 1}$, 708-712.

25. UNUTMAZ, D., and LITTMAN, D.R. (1997). Expression pattern of HIV-1 coreceptors on T cells: implications for viral transmission and lymphocyte homing. Proc. Natl. Acad. Sci. USA 94, $1615-1618$

26. RILEY, J.L., LEVINE, B.L., CRAIGHEAD, N., FRANCOMANO, T., KIM, D., CARROLL, R.G., and JUNE, C.H. (1998). Naive and memory CD4 $\mathrm{T}$ cells differ in their susceptibilities to human immunodeficiency virus type 1 infection following CD28 costimulation: implications for transmission and pathogenesis. J. Virol. 72, 8273-8280.

27. HUBER, M.A., DENK, A., PETER, R.U., WEBER, L., KRAUT, 
N., and WIRTH, T. (2002). The IKK-2/Ikappa Balpha/NF-kappa $\mathrm{B}$ pathway plays a key role in the regulation of CCR3 and eotaxin1 in fibroblasts. A critical link to dermatitis in Ikappa Balpha-deficient mice. J. Biol. Chem. 277, 1268-1275.

28. LIU, R., ZHAO, X., GURNEY, T.A., and LANDAU, N.R. (1998). Functional analysis of the proximal CCR5 promoter. AIDS Res. Hum. Retroviruses 14, 1509-1519.

29. TREBILCOCK, G.U., and PONNAPPAN, U. (1998). Nuclear factor-kappaB induction in $\mathrm{CD}_{45 \mathrm{RO}^{+}}$and $\mathrm{CD}_{45 \mathrm{RA}^{+}} \mathrm{T}$ cell subsets during aging. Mech. Ageing Dev. 102, 149-163.

30. GINN-PEASE, M.E., and WHISLER, R.L. (1998). Redox signals and NF-kappaB activation in T cells. Free Rad. Biol. Med. 25, 346-361.

31. GONDOIS-REY, F., GRIVEL, J.C., BIANCOTTO, A., PION, M., VIGNE, R., MARGOLIS, L.B., and HIRSCH, I. (2002). Segregation of R5 and X4 HIV-1 variants to memory T cell subsets dif- ferentially expressing CD62L in ex vivo infected human lymphoid tissue. AIDS 16, 1245-1249.

Address reprint requests or correspondence to:

Dr. Raymond Yung

Cancer Center and Geriatrics Center Building, Room 5312 1500 East Medical Center Drive Ann Arbor, MI 48109-0940

Tel: (734) 647-9746

Fax: (734) 936-9220

E-mail: ryung@umich.edu

Received 17 April 2003/Accepted 17 June 2003 
This article has been cited by:

1. Umberto De Fanis, George C. Wang, Neal S. Fedarko, Jeremy D. Walston, Vincenzo Casolaro, Sean X. Leng. 2008. T-Lymphocytes Expressing CC Chemokine Receptor-5 Are Increased in Frail Older Adults. Journal of the American Geriatrics Society 56:5, 904-908. [CrossRef]

2. 2003. Anti-Aging Medicine LiteratureWatchAnti-Aging Medicine LiteratureWatch. Journal of Anti-Aging Medicine 6:4, 341-347. [Citation] [PDF] [PDF Plus] 